\title{
Esophageal functional disorders in the pre-operatory evaluation of bariatric surgery
}

\author{
Eponina Maria de Oliveira LEMMEE ${ }^{1}$, Angela Cerqueira ALVARIZ² and Guilherme Lemos Cotta PEREIRA ${ }^{3}$
}

Received: 28 September 2020 Accepted: 11 December 2020

\begin{abstract}
Background - Obesity is an independent risk factor for esophageal symptoms, gastroesophageal reflux disease (GERD), and motor abnormalities. When contemplating bariatric surgery, patients with obesity type III undergo esophagogastroduodenoscopy (EGD) and also esophageal manometry (EMN), and prolonged pHmetry (PHM) as part of their pre-operative evaluation. Objective - Description of endoscopy, manometry and pHmetry findings in patients with obesity type III preparing for bariatric surgery, and correlation of these findings with the presence of typical GERD symptoms. Methods - Retrospective study in which clinical symptoms of GERD were assessed, focusing on the presence of heartburn and regurgitation. All patients underwent EMN, PHM and most of them EGD. Results - 114 patients ( 93 females-81\%), average age 36 years old, average BMI of 45.3, were studied. Typical GERD symptoms were referred by $43(38 \%)$ patients while $71(62 \%)$ were asymptomatic. Eighty two patients ( $72 \%$ of total) underwent EGD and 36 (42\%) evidenced esophageal abnormalities. Among the abnormal findings, hiatal hernia was seen in 36\%, erosive esophagitis (EE) in 36\%, and HH+EE in 28\%. An abnormal EMN was recorded in 51/114 patients (45\%). The main abnormality was a hypotensive lower esophageal sphincter (LES) in 32\%, followed by ineffective esophageal motility in 25\%, nutcracker esophagus in 19\%, IEM + hypotensive LES in 10\%, intra-thoracic LES (6\%), hypertensive LES (4\%), aperistalsis (2\%) and achalasia (2\%). Among the 43 symptomatic patients, $23(53 \%)$ had abnormal EMN and 31/71 asymptomatic cases (44\%) also presented this finding $(P=0.30)$. PHM showed abnormal reflux in 60/114 patients $(53 \%)$, with a predominance of bi-positional reflux (42\%), followed by supine reflux (33\%) and upright reflux (25\%). Abnormal PHM was found in $26 / 43$ symptomatic cases $(60 \%)$ and also among $34 / 71$ asymptomatic cases $(48 \%)(P=0.19)$. Conclusion-Manometric abnormalities were common in obesity type III patients, the most frequent being hypotensive LES, followed by IEM. Most patients were asymptomatic. There was no correlation between the finding of motor abnormalities and the presence of symptoms. More than half the patients had abnormal reflux at PHM. We found no significant correlation between abnormal reflux and the presence of symptoms.
\end{abstract}

Keywords - Bariatric surgery; obesity; esophageal functional disorders.

\section{INTRODUCTION}

Obesity and gastroesophageal reflux disease (GERD) are both very prevalent in developed countries, having evolved into a public health problem affecting $61 \%$ of the USA population ${ }^{(1)}$. In the last data collect in 2018, the Brazilian health authority evaluated more than 73,000 people living in different areas and found that 55.7\% of adults presented weight excess or obesity ${ }^{(2)}$. Although obesity is considered a disease in itself, it is also an important risk factor for many other diseases, such as diabetes mellitus, arterial hypertension and coronary artery disease. Obesity is an independent risk factor for esophageal symptoms, GERD and motor abnormalities ${ }^{(3)}$. Therefore, an effective control of obesity is an essential therapeutic aim, and bariatric surgery is the only effective treatment for obesity type III as it leads to sustained weight loss and improvement of co-morbidities. There are several approaches to the surgical treatment of patients with obesity type III, each one with its particular advantages and disadvantages ${ }^{(1)}$. When determining the appropriate surgical strategy, clinicians should consider patient history, preoperative symptoms, pre-existing esophageal motility and esophageal acid exposure. It is still unclear whether candidates to bariatric surgery should perform pre-operative reflux testing or not, but they frequently undergo esophagogastroduodenoscopy (EGD), pHmetry (PHM) and esophageal manometry $(\mathrm{EMN})$ as part of their pre-operative evaluation. This paper reports findings in obesity type III patients, and correlates them with the presence of typical symptoms of GERD.

\section{METHODS}

This is a retrospective pre-operative study of obesity type III patients $(\mathrm{BMI}=/>40)$ heading to for bariatric surgery. Our study focused on the presence of typical symptoms of GERD, such as heartburn and regurgitation. Most patients underwent EGD and all had EMN and PHM.

\section{Esophagogastroduodenoscopy}

We accessed the presence of hiatal hernia, defined as an esophago-gastric junction situated $2 \mathrm{~cm}$ or more above the diaphragmatic impression on the esophagus. Esophagitis was defined and described according to the Los Angeles classification criteria ${ }^{(4)}$.

Declared conflict of interest of all authors: none

Disclosure of funding: no funding received

${ }^{1}$ Universidade Federal do Rio de Janeiro, Departamento de Clínica Médica, Rio de Janeiro, RJ, Brasil. ${ }^{2}$ Universidade Federal do Rio de Janeiro, Departamento de Gastroenterologia, Rio de Janeiro, RJ, Brasil. ${ }^{3}$ Membro Titular do Colégio Brasileiro de Cirurgia Digestiva; Membro Titular da Sociedade Brasileira de Cirurgia Laparoscópica, Brasil.

Research performed at: ESOFAGOLAB - Esophageal Motility and pH Clinic - Rio de Janeiro, RJ, Brasil.

Corresponding author: Eponina Maria de Oliveira Lemme. E-mail: eponina@hucff.ufr.br 


\section{Esophageal manometry}

In our manometric studies, we employed a polyvinyl catheter with eight lumens, $4.5 \mathrm{~mm}$ external diameter and four proximal openings $5 \mathrm{~cm}$ apart and four distal openings radially oriented at the same level. Each of the openings of this setting was connected to external pressure transducers and was perfused with distilled water originating from a system of capillary infusion (Alacer, Brazil). Intraluminal pressures were recorded in a polygraph and the digital information transferred to a computer. The lower esophageal sphincter (LES) was examined with the distal openings with the slow-pull technique, and five water swallows to evaluate the LES relaxation. The esophageal body was studied by placing the proximal openings of the catheter at 3, 8, 13 and 18 $\mathrm{cm}$ above the upper limit of the LES. Ten swallows of water at room temperature were recorded at 20 seconds intervals. At the end of the test, the readings were interpreted by means of a specific software. The manometric diagnosis followed international criteria $^{(5)}$, adapted to normal values obtained at previous studies in asymptomatic volunteers ${ }^{(6)}$.

\section{Prolonged esophageal pHmetry}

The monitoring of intra-esophageal $\mathrm{pH}$ was performed by a portable digital system (Alacer, Brasil) attached to an antimonium catheter positioned at $5 \mathrm{~cm}$ above the LES upper limit, as previously described for EMN, and linked to an external reference electrode. This exam was performed with the patient leading a normal life and a liberal diet, with restriction of citric fruits and juices and carbonated beverages only. Proton-pump inhibitors (PPIs) were discontinued 7 days, $\mathrm{H}-2$ receptor antagonist 72 hours and prokynetic drugs 24 hours before the test. We considered PHM as abnormal when the percentage of the total PHM test time with a recording below $\mathrm{pH}$ four was higher than $4.5 \%$, higher than $7.0 \%$ in the orthostatic position and $2.5 \%$ in the supine position ${ }^{(7)}$.

\section{Statistical analysis}

We used IBM SPSS Student test, and considered $P<0.05$ as the level of significance.

\section{RESULTS}

Our study included 114 patients, 93 (81\%) females, ages ranging between 19-64 years old (average age $=36$ ) and an average BMI of 45.3 (40-52). Typical symptoms of GERD (heartburn and/or regurgitation) were referred by $43(38 \%)$ patients, the remaining $62 \%$ being asymptomatic.

\section{Esophagogastroduodenoscopy}

This test was performed in 82 patients, and esophageal abnormalities were found in $36(42 \%)$. Among the abnormal cases, 13 $(36 \%)$ had hiatal hernia $(\mathrm{HH}), 13(36 \%)$ erosive esophagitis (EE) (10 with L.A. grade A and 3 with grade B) and $10(28 \%) \mathrm{HH}+\mathrm{EE}$ (4 L.A. grade A and 6 grade B).

\section{Esophageal manometry}

EMN was abnormal in 51/114 (45\%) patients. Among the abnormal readings, the predominant finding was hypotensive LES $(<10 \mathrm{mmHg})$ in $32 \%$, followed by ineffective esophageal motility $(25 \%)$, nutcracker esophagus $(19 \%)$, hypotensive LES+ ineffective esophageal motility (IEM) $(10 \%)$, intrathoracic LES $(6 \%)$, hypertensive LES (4\%), aperistalsis ( $2 \%$ ) and achalasia (2\%) (TABLE 1$)$.
TABLE 1. Abnormal esophageal manometry ( $\mathrm{n}=51 / 114$ cases $-45 \%)$.

\begin{tabular}{lcc}
\hline Abnormality & Number of patients & Percentage \\
\hline Hypotensive LES & 16 & $32 \%$ \\
IEM & 13 & $25 \%$ \\
NE & 10 & $19 \%$ \\
Hypotensive LES+IEM & 5 & $10 \%$ \\
Intrathoracic LES & 3 & $6 \%$ \\
Hypertensive LES & 2 & $4 \%$ \\
Aperistalsis & 1 & $2 \%$ \\
Achalasia & 1 & $2 \%$ \\
\hline
\end{tabular}

LES: lower esophageal sphincter, IEM: ineffective esophageal motility, NE: nutcracker esophagus.

\section{Esophageal manometry vs symptoms}

Among the 43 symptomatic patients, 23 (53\%) presented with an abnormal EMN, while 31/71 (44\%) asymptomatic cases also showed abnormal findings $(P=0.30)$ (TABLE 2).

TABLE 2. Esophageal manometry vs symptoms.

\begin{tabular}{lcc}
\hline Symptoms & Normal EMN & Abnormal EMN \\
\hline Present $=43$ & $20(47 \%)$ & $23(53 \%)$ \\
Absent $=71$ & $40(56 \%)$ & $31(44 \%)$ \\
\hline
\end{tabular}

$P=0.30$. EMN: esophageal manometry.

\section{Prolonged pHmetry}

PHM revealed abnormal reflux patterns in 60/114 patients (53\%). The bi-positional reflux pattern predominated, being registered in $25(42 \%)$ of cases followed by supine reflux pattern in 20 $(33 \%)$ and upright reflux pattern in $15(25 \%)$ (TABLE 3$)$. Twentysix $(60 \%)$ of the symptomatic patients showed an abnormal PHM, while 34/71 (48\%) of asymptomatic cases also presented such findings. There was no significant correlation between the presence of reflux symptoms and the finding of an abnormal reflux pattern $(P=0.19)$ (TABLE 4).

TABLE 3. Abnormal prolonged pHmetry (60/114 cases $-53 \%)$.

\begin{tabular}{lcc}
\hline Reflux pattern & Number of patients & Percentage \\
\hline Bi-positional & 25 & $42 \%$ \\
Supine & 20 & $33 \%$ \\
Upright & 15 & $25 \%$ \\
\hline
\end{tabular}

TABLE 4. Prolonged pHmetry vs symptoms.

\begin{tabular}{lcc}
\hline Symptoms & Normal PHM & Abnormal PHM \\
\hline Present $(\mathrm{n}=43)$ & $17(40 \%)$ & $26(60 \%)$ \\
Absent $(\mathrm{n}=71)$ & $37(52 \%)$ & $34(48 \%)$ \\
\hline
\end{tabular}

$P=0.19$. PHM: prolonged pHmetry. 


\section{DISCUSSION}

Obesity occurs in about $10 \%$ of the world population and is an important factor in the genesis of GERD symptoms, hiatal hernia, esophagitis, and Barrett's esophagus ${ }^{(1,3)}$. Obesity type III patients present with co-morbidities such as arterial hypertension, diabetes mellitus and coronary artery disease, as well as a significant worsening of their quality of life. Bariatric surgery is an important contribution to this group of patients that fail to manage their excessive weight by more traditional methods. Candidates for bariatric surgery undergo EGD, and, in most centers, EMN and PHM.

Obesity type III patients often present with symptoms of GERD, such as heartburn and regurgitation in up to $60 \%$ of cases $^{(1)}$. In our study, they were present in $38 \%$, a finding parallel to that in another study involving 154 candidates to bariatric surgery, where $30.51 \%$ presented with heartburn ${ }^{(8)}$.

At EGD, it is known that obesity predisposes to hiatal hernia due to increased intra-abdominal pressure pushing the LES into the thorax. It also weakens the normal mechanisms that prevent gastro-esophageal reflux ${ }^{(3)}$. A large study involving 1,213 patients and correlating the presence of hiatal hernia and erosive esophagitis with BMI demonstrated that obese subjects had 4.2 times more chance to present with hiatal hernia than lean subjects. It also showed that the prevalence of the latter in obese patients was $40 \%$ as compared with $12.5 \%$ in the general population ${ }^{(9)}$. Associated esophagitis was found in $38.9 \%$ of $\mathrm{HH}$ patients and $\mathrm{HH}$ was an independent predictor of esophagitis. The prevalence of esophagitis increased along with the increase of BMI. In our study erosive esophagitis was found in 23 of the $82(28 \%)$ patients that underwent EGD. They all classified as A or B of the LA classification, in agreement with a national study which found esophagitis in $25.2 \%$ of 154 candidates to bariatric surgery ${ }^{(8)}$.

According to a recent paper on the Lyon Consensus, LA grade A can be observed in asymptomatic people and the prevalence of grade $\mathrm{B}$ varies among observers. Therefore, the Consensus recommends pHmetry to confirm abnormal reflux in these patients ${ }^{(10)}$.

Our manometric studies were abnormal in $45 \%$ of all obese patients, hypo-contractile abnormalities being the most frequent finding. In other studies, manometric abnormalities have also been found in obese and obesity type III patients. In one of these, EMN was abnormal in $51 \%$ of 53 obesity type III patients, hypomotility being found in $85 \%$ of the abnormal tests or $43 \%$ of the whole group ${ }^{(11)}$. Another study found hypotensive LES in $46 \%$ of 88 patients ${ }^{(12)}$.

Nutcracker esophagus (NE) was the third most frequent abnormality in our group. This hypercontractile motor disorder shows characteristically high amplitude waves in the distal esophagus ${ }^{(13)}$ and its main symptoms are chest pain and dysphagia ${ }^{(13,14)}$. In $30-40 \%$ of patients with NE there is associated reflux as seen by PHM, and studies show that there is no difference in clinical and manometric findings between groups with and without reflux ${ }^{(15)}$. Thus, we suggest NE patients should undergo PHM, since this disorder is managed with calcium channel-blockers, which lower the LES pressure and increase the possibility of reflux ${ }^{(13)}$.

Another study stresses the importance of obesity as a risk factor for GERD and a potential modulator of esophageal motility. Fornari et al. studied 332 patients categorized as GERD and non-GERD after clinical assessment, esophageal conventional manometry and $\mathrm{pH}$ monitoring. Non-obese and obese patients were compared regarding distal esophageal amplitude, LES pressure, manometric diagnosis and esophageal acid exposure. The obese patients differed from non-obese in terms of esophageal motility and reflux, regardless of the presence of GERD. Obese patients showed stronger peristalsis and increased acid exposure in the esophagus ${ }^{(16)}$.

One of our patients had the manometric diagnosis of achalasia. This has already been reported in obesity type III patients ${ }^{(17)}$. The main symptoms of achalasia are dysphagia, regurgitation and weight loss ${ }^{(18)}$. Some patients present overlapping clinical features, which in some cases may suggest GERD, due to the occurrence of frequent regurgitation and heartburn, seen in at least $40 \%{ }^{(19)}$. The association of untreated achalasia and obesity type III stresses the importance of this diagnosis in the pre-operative evaluation of bariatric surgery ${ }^{(20)}$.

Another study using pre-operative EMN for the selection of patients to vertical gastrectomy found abnormal results in $49 \%$ of 73 patients, hypertension of the LES being the most frequent finding, followed by an increased amplitude of peristaltic waves (not defined by the authors as NE) and hypotensive LES ${ }^{(21)}$.

Forty-three of our $114(38 \%)$ patients had typical reflux symptoms. Manometric abnormalities were not predictive of the presence of symptoms in obesity type III patients, although our study only focused on typical GERD symptoms. A high prevalence of asymptomatic motor abnormalities have been found on obesity type III patients ${ }^{(22)}$. EMN performed in 111 such patients showed motor abnormalities in $61 \%$, mostly a hypocontractile pattern, but there were also 16 cases of NE eight with diffuse spasm and one with achalasia. Most of the latter referred no dysphagia or were totally asymptomatic. These findings suggest to the authors, that some patients with obesity type III may represent instances of abnormal visceral sensitivity ${ }^{(22)}$.

Earlier studies on prolonged pHmetry mentioned abnormal reflux in $30-42 \%$ of obesity type III patients ${ }^{(23,24)}$. The prevalence of abnormal reflux in these patients is high, even in the absence of associated esophagitis. In a group of 50 obesity type III patients evaluated for bariatric surgery, $28(56 \%)$ had abnormal reflux a $\mathrm{PHM}^{(1)}$. Another study found abnormal PHM in $65 \%$ of 88 patients $^{(11)}$.

Similarly, there was no significant difference between abnormal reflux and the presence of typical GERD symptoms (TABLE 4), suggesting that patients with abnormal reflux and obesity type III can be asymptomatic. In another study half of the asymptomatic patients presented with abnormal reflux, while in the symptomatic group the proportion of reflux rose to $80 \%$ $(P>0.42)$. The authors stress the relationship between the presence of symptoms and reflux, although the absence of symptoms does not rule out an abnormal pHmetry ${ }^{(12)}$. Another paper suggests that patients with esophagitis and symptoms of reflux should undergo EMN and PHM in the pre-operative evaluation of bariatric surgery, especially those facing restrictive procedures. These tests would not be necessary in the absence of symptoms or esophagitis, since results were similar to those in a group of asymptomatic volunteers $^{(25)}$. This indicates that the literature on significance of symptoms is controversial.

Our study has some limitations. This is a retrospective study and we did not access to the data of all patients. the endoscopy had been performed by $72 \%$ of the patients up to the moment the functional tests were performed.

We are unaware if the patients underwent surgery or what procedure was carried out. Besides, we do not know if the findings of the tests influenced the decision process regarding the type of 
surgery. In addition, we employed conventional manometry and the more utilized esophageal motor disorders classification of Spechler and Castell ${ }^{(5)}$.

Recently the indication of esophageal functional tests, manometry and ph-monitoring in pre-operatory evaluation of bariatric surgery has been an emerging recommendation ${ }^{(26)}$

In summary, this is a descriptive study about functional tests in a group of obesity type III patients before surgery. The data presented here were similar to those in the pertinent literature and show the lack of correlation between typical symptoms and abnormal tests.

We did not have in our objectives, to do any recommendations based in these findings. However, more studies are needed, with special emphasis on the follow-up of patients after surgery.

\section{CONCLUSION}

Manometric abnormalities were observed in patients with obesity type III, a hypotensive LES being the most frequent followed by ineffective esophageal motility. Most patients were asymptomatic.
More than half of them presented with abnormal reflux at prolonged pHmetry. There was no significant correlation between abnormal reflux and the presence of symptoms. There was no correlation between abnormal motility findings and the presence of symptoms.

\section{ACKNOWLEDGEMENTS}

The authors would like to thank Felix R Zyngier, M.D., M.Sc. for reviewing and translating this article.

\section{Authors' contribution}

Lemme EMO: main researcher, data collection, analysis, and writing of the text. Alvariz AC: data collection, additional writing and text review. Pereira GLC: text review.

\section{Orcid}

Eponina Maria de Oliveira Lemme: 0000-0002-1916-9274.

Angela Cerqueira Alvariz: 0000-0001-8619-136X.

Guilherme Lemos Cotta Pereira: 0000-0001-5196-3796.

Lemme EMO, Alvariz AC, Pereira GLC. Distúrbios funcionais esofágicos na avaliação pré-operatória de cirurgia bariátrica. Arq Gastroenterol. 2021;58(2):190-4.

RESUMO - Contexto - A obesidade é fator de risco independente para sintomas esofagianos, doença do refluxo gastroesofágico (DRGE) e alterações motoras. Pacientes com obesidade tipo III, candidatos à cirurgia bariátrica foram submetidos a endoscopia digestiva alta (EDA) e também realizaram esofagomanometria (EMN) e pHmetria prolongada (PHM) como parte da avaliação pré-operatória. Objetivo - Em um grupo de pacientes com obesidade tipo III em pré-operatório de cirurgia bariátrica, descrever os achados endoscópicos, manométricos e pHmétricos, correlacionando-os com a presença de sintomas típicos de DRGE. Métodos - Estudo retrospectivo, de pacientes com obesidade tipo III, candidatos a cirurgia bariátrica. A avaliação clínica focalizou a presença de sintomas típicos de DRGE (pirose/regurgitação); todos foram submetidos a EMN, PHM e a maior parte à EDA, realizada previamente. Resultados - Foram incluídos 114 pacientes, 93 (81\%) do sexo feminino, média de idade de 36 anos e IMC médio de 45,3. Sintomas típicos de refluxo foram referidos por $43(38 \%)$ pacientes e $71(62 \%)$ eram assintomáticos. EDA foi realizada por $82(72 \%)$ pacientes, havendo anormalidades esofagianas em $36(42 \%)$. Entre os anormais, havia hérnia hiatal (HH) em 36\%, esofagite erosiva (EE) em $36 \%$ e HH + EE em $28 \%$. A EMN foi anormal em 51/114 (45\%). Entre os anormais, predominou o esfíncter esofagiano inferior (EEI) hipotenso em $32 \%$, seguido por motilidade esofagiana ineficaz (MEI) em 25\%, esôfago em quebra-nozes (19\%), EEI hipotenso + MEI (10\%), EEI intra-torácico (6\%), EEI hipertenso $(4 \%)$, aperistalse ( $2 \%$ e acalasia (2\%). Dentre os 43 sintomáticos, $23(53 \%)$ apresentavam EMN anormal, sendo que em 31 dos 71 (44\%) assintomáticos a EMN também era anormal $(P=0,30)$. A PHM revelou refluxo anormal em $60(53 \%)$ pacientes. Predominou o refluxo anormal biposicional (42\%) seguido do refluxo supino (33\%) e refluxo ereto (25\%). Dentre os 43 pacientes sintomáticos, $26(60 \%)$ apresentavam PHM anormal, sendo que em 34 dos 71 assintomáticos a PHM também era anormal (48\%) - P=0,19. Conclusão - Alterações manométricas foram comuns em obesidade tipo III, sendo as mais frequentes o EEI hipotenso, seguida de motilidade ineficaz. A maioria dos pacientes era assintomática. Mais da metade dos pacientes apresentou refluxo anormal à PHM. Não houve diferença significativa entre o achado de refluxo anormal e a presença de sintomas. Não houve relação entre o achado de alterações motoras e a presença de sintomas.

Palavras-chave - Cirurgia bariátrica; obesidade; alterações funcionais do esôfago.

\section{REFERENCES}

1. Ortega J, Escudero MD, Mora F, Sala C, Flor B, Martinez-Valls J et al. Outcome of esophageal function and 24-hour esophageal $\mathrm{pH}$ monitoring after vertical banded gastroplasty na Roux-em-Y gastric bypass. Obes Surg. 2004;14:1086-94.

2. Brasil. Ministério da Saúde. Vigitel e plano de Orçamento Familiar 2018-2019/ IBGE/ Min.da Saúde.

3. Lagergren J. Influence of obesity on the risk of esophageal disorders. Natural Rev Gastr Hepatol. 2011;8:340-7.

4. Lundell LR, Dent J, Bennett JR, Blum AL, Armstrong D, Galmiche JP, et al Endoscopic assessment of oesophagitis: clinical and functional correlates and further validation of the Los Angeles classification. Gut. 1999;45:172-80.

5. Spechler SJ, Castell DO. Classification of esophageal Motility Abnormalities. Gut. 2001;49:145-51
6. Lemme; EMO, Domingues GR, Silva LFD, Firman CG, Pantoja JAS. Esophageal manometry: preliminary values in health adult volunteers. GED gastroenterol. Endosc dig. 2001;20:29-35.

7. Jamieson JR, Stein HJ, DeMeester, TR Bonavina, L Schwizer, W Hinder, RA Albertucci M. Ambulatory 24-hour esophageal pH monitoring: normal values, optimal thresholds, specificity, sensitivity and reproducibility. Am J Gastroenterol.1992;87:1102-11.

8. Oliveira GHR, Araújo GF, Faria MS, Dominici AJ. Upper gastrointestinal endoscopic findings in obese patients candidates to bariatric surgery. GED gastroenterol. endose dig. 2005;24:239-42.

9. Wilson LJ, Ma W, Hirschowitz BI. Association of obesity with hiatal hernia and esophagitis. Am J Gastroenterol. 1999;94: 2840-44. 
10. Gyawali CP, Kahrilas PJ, Savarino E, Zerbib F, Mion F, Smout AJPM, et al Modern diagnosis of GERD: The Lyon Consensus. Gut. 2018:1351-62.

11. Coté-Daigneault J, Leclerc P, Joubert J, Bouin M. High prevalence of esophageal dysmotility em asymptomatic obese patients. Can J Gastroenterol Hepatol 2014;28:311-4.

12. Martin-Perez J, Arteaga-Gonzalez J, Martin-Malagon A, Díaz-Luis H, Casanova-Trujillo C, Carrillo-Pallarés A. Frequency de abnormal esophageal acid exposure in patients eligible for bariatric surgery. Surg Obes Relat Dis. 2014;10:1176-80.

13. Benjamin SB, Castell DO. The nutcracker esophagus and the spectrum of esophageal motor disorders. Curr Concepts Gastroenterol. 1980;5:3-8

14. Silva LF, Lemme EMO. Nutcracker esophagus: clinical evaluation of 97 patients Arq Gastroenterol. 2000;37:217-23.

15. Silva LF, Lemme EMO - Are there any differences between nutcracker esophagus with and without reflux?.Dysphagia. 2007; 22:245-50.

16. Fornari F, Sidia M, Callegari-Jacques SM, Oliveira Dantas R, Scarsi AL Ruas LO, Barros SGS. Obese patients have stronger peristalsis and increased acid exposure in the esophagus. Dig Dis Sci. 2011;1420-26.

17. O'Rourke RW, Jobe BA, Spight DH. Simultaneous surgical management of achalasia and morbid obesity. Obes Surg. 2007; 17:547-49.

18. Zaninotto G, Bennett C, Boeckxstaens G, Costantini M, Ferguson MK, Pandolfino JE, et al. The 2018 ISDE achalasia guidelines. Dis Esophagus. 2018;31:1-29.
19. Cochlar VL, Lemme EMO. Aspectos clínicos e epidemiológicos da acalásia em pacientes do HUCFF.-UFRJ. GED 14(suppl):S30, 1995.

20. Fisichella PM, Orthopoulos G, Holmstrom A, Patti MG. The surgical management of achalasia in the obese patients. J Gastrointestinal Surg. 2015;19:1139-43.

21. Valezi AC, Herbella FA, Mali-Junior J Menezes MA, Liberatti M, Sato RO. Preoperative manometry for the selection of obese people candidate to sleeve gastrectomy. Arq Bras Cir Dig. 2017;30:222-4.

22. Jaffin BW, Knoepflmacher P, Greenstein R. High prevalence of asymptomatic esophageal motility disorders among morbidly obese patients. Obes Surg. 1999;9:360-95.

23. Rigaud D, Marrouche M, Le Moel G, J Vatier, Paycha F, Cadio, Naoui N, Mignon M. Factors of gastroesophageal acid reflux in severe obesity Gastroenterol. Clin Biol. 1995; 19:818-25.

24. Lundell L, Ruth M, Sandberg S, Bove-Nielsen M. Does massive obesity promote abnormal gastroesophageal reflux? Dig Dis Sci. 1995;40:1632-5.

25. Tolone S, Lomongelli P, Del Genio G, Rossetti G, Amoroso V, Schettino P, et al. Gastroesophageal reflux disease and obesity: do we need to perform reflux testing in all candidates to bariatric surgery. Int J Surg 2014;12 (Suppl 1):s173-7.

26. Gyawali PC, Bortoli N, Clarke J, Marinelli C, Tolone S, Roman S, Savarino E. Indications and interpretation of esophageal function testing. Ann N.Y. Acad Sci. 2018;1434:239-53. DOI:10.1111/nyas.13709;1-15. 